\title{
POSSIBLE CONCEPTUALIZATION OF CULTURE AND CULTURAL DIFFERENCE IN SOCIOLOGICAL PROFILE RESEARCHES
}

\author{
Author \\ Norbert Tóth \\ University of Debrecen (Hungary) \\ E-mail address: \\ toth.norbert@ped.unideb.hu
}

\author{
Lectors \\ Antal Lovas Kiss (Ph.D) \\ University of Debrecen (Hungary) \\ Gyula Varga (Ph.D) \\ University of Debrecen (Hungary) \\ ...and two anonymous reviewers
}

Tóth, Norbert (2020). Possible Conceptualization of Culture and Cultural Difference in Sociological Profile Researches. Különleges Bánásmód, 6. (4). 91-100. DOI 10.18458/KB.2020.4.91

\begin{abstract}
The fundamental concept of the paper is in accordance with the thesis of pedagogical anthropology claiming that the school success of students in minority status is in strictly correlation with the recognition of the cultural difference by the education system. From the point of view of empirical researches related to pedagogical anthropology and education of sociology, the conceptualization of culture and cultural difference is a vital important factor. The paper intends to elaborate on the possible interpretation of the these notions based on the relevant national and international literature.
\end{abstract}

Keywords: culture, cultural difference, social mobility

Disciplines: pedagogy, education of sociology

\begin{abstract}
Absztrakt
A KULTÚRA ÉS A KULTURÁLIS DIFFERENCIA KONCEPTUALIZÁLÁSA A NEVELÉSSZOCIOLÓGIAI PROFILÚ KUTATÁSOKBAN

A tanulmány a pedagógiai-antropológia abból az alapkoncepciójából indul ki miszerint a kisebbségi státuszban lévő tanulók iskolai sikeressége szempontjából döntő jelentőségú, hogy az oktatási rendszer felismerje, hogy a kisebbségi miliőből érkező diákok tanulmányi sikertelensége a kulturális differenciával hozható összefüggésbe. Az erre a jelenségre reflektáló pedagógiai-antropológiai és nevelésszociológiai profilú empirikus kutatások elméleti kontextusa kiindulópontjának a kultúra és a kulturális differencia fogalmi keretrendszerének a meghatározása áll. Jelen tanulmány, a hazai és nemzetközi szakirodalomra támaszkodva, definíciós alternatívákat kíván nyújtani, s nevelésszociológiai perspektívából értelmezni azokat.
\end{abstract}

Kulcsszavak: kultúra, kulturális differencia, társadalmi mobilitás

Diszciplína: pedagógia, nevelésszociológia 
In the following paper I tend to embark on one of the theoretical features of anthropology of educations or also known as pedagogical anthropology. The reflective scientific interpretation cannot be considered as an objective of the current treatise, but I regard it essential to mention the main principles concerning the targeted subdiscipline and to highlight the particular aspect that I intend to reflect on within the broader theoretical framework that can be associated with anthropology of education.

Generally formulating, it can be claimed that anthropology of education is a branch of educational research that was emerged in the United States during the years of 1950s. After some decades it became prevalent in Europe, primarily in Germany and in the United Kingdom. The border of the expansion of the anthropology of education was not ceased in Europe. The theoretical and methodological paradigms of it have been appeared in Japan, India or even in China (Kathryn, 2012).

Anthropology of education focuses on the socialization function of schools, cultural transmission, and the process of enculturation. Furthermore, the examination of the role of ethnocentrism from the perspective of reproduction of inequalities is also a key factor. Over and above, Ionnais Sideris calls attention to the following: „Teachers and educators can benefit from their understanding of the anthropological approach in many ways. The mastering of the methodological tools of anthropology, such as the practice of gathering multiple perspectives from different stakeholders in the school and its environment, can be useful to them in order to develop and achieve a more inclusive decisionmaking. An anthropology can approach to the study of the parallel process of teaching and learning focuses on how people learn during their childhood (and beyond) and on what they take for granted as cultural knowledge..." (Ionnais, 2012, 18-19). Taking into account the above cited findings, it can be declared that minority students' cul- tural background has to be understood by the school for the sake of successful school carrier. If the educational institutions fail to comprehend or even neglect minority students' socio-cultural features and the impact that they have on the school performance, students will encounter problems that are really demanding to cope with on the longrun. It is one of the reasons why it is vital to emphasize the cultural diversity or cultural differences from the view of school achievement.

The empirical researches concerning the detailed phenomenon come from the field of sociology of education. As such, the accurate interpretation of culture and cultural differences is inevitable. The appropriate discipline to outline the possible definitions of culture and cultural differences is cultural anthropology. Based on the international literature, I provide a comprehensive picture of these two notions. I do hope that scholars dealing with sociological profile scrutiny can regard the current paper as a toolkit for feasible conceptualization of culture and cultural differences.

\section{Concept of culture and cultural difference}

Sociological research in education emphasizes in several respects that the key to children's school success is to be found in family socialization, and thus the status of the family in society is a key factor, as this determines the pattern of behaviour that children experience directly and indirectly and later gradually internalize (Kende, 2001). From the point of view of the treatise, we would supplement this idea with the fact that in our opinion not only the role of social status and socio-cultural background should be emphasized, but also the family and, more broadly, the cultural characteristics of the examined ethnicity. Milton Yinger's scientific explanations also prove that the additional condition of a person's social definition is their cultural peculiar- 
ity, and vice versa, the cultural peculiarities of a person are characterized by a certain social dimension (Milton, 2002).

If we try to interpret culture in a nominal sense, then cultivating something has meaning. It was also used in this sense by large-format ancient thinkers. Marcus Portius Cato uses the word cultura agri (cultivation of the earth), and in the texts of Marcus Tulius Cicero appears cultura animi (cultivation of the soul) (Németh and Pukánszky, 1996). In the „modern age”, an explicit explanation of the concept of culture is also a central problem for professionals practicing cultural research as an academic discipline.

A demonstrative example of this is the work of Kroeber and Kluckhohn, who collected 164 definitions in the analysis of the international literature in the early 1950s (Prónai, 1995). It is clear that the range of alternatives for explaining conceptual frameworks has expanded in the decades since. In our case, however, it must be emphasized that the concepts of culture presented below are discussed from the perspective of cultural anthropologists. This means that the findings of sociology in this regard are not relevant to us, that culture is a higher intellectual activity that includes various arts, literature, painting or even music (Anthony, 2008). The concept of culture is therefore not interpreted as high culture, but on a much broader scale.

The first concept of real culture, accepted by the scientific public is related to the name of Edward Burnett Tylor, of British descent, who puts it this way: „...culture or civilization, in its full ethnographic sense, is the complex whole that which includes knowledge, belief, art, law, morals, custom, and any other capabilities and habits acquired by man as a member of socie-ty" (Leach, 1996, 56).

Tylor thus emphasizes that man, as an individual, is part of a complex society, and that culture is at least as complex a phenomenon as society itself. As a result, it is vital for the individual to acquire proficiency in the cultural characteristics that are an integral part of society. In our interpretation, cultural characteristics can be grouped according to two aspects, we can talk about theoretical cultural elements (knowledge, belief, art, law, tradition) and practical ones (ability and custom).

Tylor's cultural thinking was later taken as a starting point by several anthropologists, including Franz Boas, who in 1911 said the following, somewhat expanding Tylor's thoughts: „Culture can be defined as the totality of mental and physical responses and activities. They characterize the behaviour of individuals who form social groups, both as a group and individually, in relation to their natural environment, other groups, members of their own group, and themselves. Also included are the products of the activities and their role in the lives of the groups. However, mere listing does not yet constitute a culture; more than that, since its elements are not independent of each other, they have structure." (Letenyei, 2012, 28.)

Beyond all this, there are interpretations that approach culture from the perspective of cognitive anthropology. According to these views, culture is a set of implicit (unspoken) and explicit (spoken), that is, actually unconscious and conscious knowledge, located in the mental lexicon of the individual (Forray and Hegedûs 1998). This view is partly represented by Ruth Fulton Benedict, who emphasizes that a person's personality is formed on the basis of the impulses of a given culture, and as a result cultural differences develop within a given society (Prónai, 1995). In this regard, Benedict points out that every society has a cultural pattern (cultural pattern), and, as a result, the cultures that exist in society form a pattern of behaviour on the basis of which the individual develops his or her own way of life, habits and value system. From the point of view of our topic, the concept of Benedict culture is especially important to us because it emphasizes the importance of education.

Using the theoretical framework of cognitive anthropology, Margaret Mead expressed similar ideas: 
„Culture means human culture, the whole complex of traditional behaviour developed by the human race, which is then learned by each generation. (...) The definition of a culture is less accurate. It may mean forms of traditional behaviour which are specific to a particular society, or to a group of societies, or to a particular race, or to a particular area, or to a particular period.” (Borsányi, 2012, 27.)

The explanations of the American anthropologist are considered authoritative for our research topic in several respects. On the one hand, we consider it important to state that the acquisition of culture is the result of a learning process.

On the other hand, we consider it a particularly important idea that culture has diverse elements within a complex society, its meaning may vary depending on the given local community, at the same time, communities of common ethnicity have universal cultural contents that distinguish the culture of a given ethnicity (e.g., Roma individuals) from the culture of the majority society. We define cultural difference as a product of this phenomenon.

Moreover, closely related to all this is Margaret Mead's claim that culture refers to a „certain period". For us, this is justified in the form that we do not consider Roma culture to be a static phenomenon, for we assume that the Roma culture acclimatizes to a certain extent to the conditions of the given era, all in such a way that there are constant elements that are independent of the temporal coordinates.

In order to clarify the conceptual framework more precisely, we need to refer to the anthropological currents that interpret culture in the socalled ,additive” sense (Prónai, 1995).

One of the main features of these concepts is that they do not take a position on the priority of individual cultural elements, nor do they emphasize the interference between the sub-elements, so the contents that make up culture must be evaluated and examined on their own. In sharp contrast, the representatives of the "integrative" trend believe that the most important factor in defining culture is to shed light on the form in which the different cultural elements are integrated and the relationship that can be discovered between them.

One of the prominent representatives of the trend is Bronislaw Malinowski, who considers culture to be an indispensable tool for everyday activities: „Culture is essentially a toolkit that allows a person to cope with the specific problems he or she faces while meeting his or her needs in his or her environment. A system of objects, activities, and attitudes, each part of which is an instrument existing for a purpose..., [and] the various elements of which are interdependent." (Borsányi, 2012, 28.)

Looking at the international literature, we should also refer to the work of Claude Lévi-Strauss and Clifford Geertz. Lévi-Strauss emphasizes the relationship between language and culture, arguing that language can be seen primarily as a product of culture, as the language used in society reflects the general culture of the community (Clifford, 2001). In his interpretation, he sees language as a condition of culture.

In researching culture, Geertz emphasizes understanding of symbols as meaningful and emphasizes that culture should be seen as an integrated whole, as it is collective within the community. As a result, each member of the community shares cultural knowledge, and all this is further inherited through socialization (Clifford, 2001).

Hungarian anthropologists correlate the definition of culture to a large extent with the interpretations of foreign experts. We would like to highlight the findings of Marida Hollós, who is of the opinion that although the definition of the conceptual set of cultures varies widely, there are still contents that can be discovered collectively for all cultures (Hollós, 1997). One such attribute is that culture is common, that is, it is shared by all members of the community. According to Hollós, culture is learned, based on symbols and integrated, thus, all 
its elements interact and are to be interpreted together. It is also worth referring to László Borsányi, who emphatically emphasizes the impact and power of culture on people. He argues that human activities manifested by culture, which contradict biological instincts can only be controlled by the framework provided by culture (Letenyei, 2012). Here, for example, Borsányi thinks of patterns of behaviour, such as the fact that one does not consume food that is considered unclean in terms of one's culture, or that one does not exhibit behaviour that conflicts with the set of norms represented by one's own community. Péter Niedermüller sharply expressed in his thesis that cultural anthropology „democratized" the concept of culture (Niedermüller, 1994). This is the deadlock when culture is no longer seen not only in an aesthetic sense and with values, but also in terms of human behaviour patterns. Niedermüller further claims that in the case of the conceptual delimitation of culture, one must think of the inner domains of appearance behind the behaviour, which he calls intersubjective reality (Niedermüller, 1994).

Describing and interpreting the concept of culture in different disciplines and their representatives would be a seemingly endless process. We emphasize, therefore, that we could not aim for completeness in the above analysis, and we are aware that our analysis could be outlined along several other alternatives.

We consider the statement of Katalin R Forray that the researcher's task is to select the cultural characteristics that she considers important for her research to be authoritative (Forray and Hegedús, 2003).

Representing this research attitude, in the following, for the sake of easier transparency, we summarize the concepts of culture presented above in the form of tables at the level of headings (1.table).

1. table: Conceptualization of culture (source: the Author)

\begin{tabular}{|l|l|}
\hline \multicolumn{1}{|c|}{ Researcher } & \multicolumn{1}{c|}{ Conceptualization of culture } \\
\hline Edward Burnett Tylor & Knowledge, tradition, ability, custom. \\
\hline Franz Boas & The totality of mental and physical activities. \\
\hline Ruth Fulton Benedict & Cultural pattern importance of nurturing. \\
\hline Margaret Mead & Traditional forms of behavior (society, group, race). \\
\hline Bronislaw Malinowski & Toolbox of everyday activities. \\
\hline Clifford Geertz & Relationship between culture and language. \\
\hline Claude Lévi-Strauss & Symbols. Intergraded whole. \\
\hline Marida Hollós & Common, acquired. Interaction among components. \\
\hline László Borsányi & Manifesto of human behavior pattern. \\
\hline Péter Niedermüller & The 'democratization' of the concept. Intersubjective reality. \\
\hline
\end{tabular}


From the aspect of education of sociology, we view culture as a set of patterns of behaviour that an individual acquires through socialization. In this sense, the socialization medium, the milieu, plays a significant role in terms of the cultural contents represented by the individual. Projected for education and schooling, this means that the values, norms, attitudes (cultural elements in general) preferred and mediated by the given community and family appear in the learner's relation to school and learning, the detectable consequences of which are manifested in the learning outcomes. At the same time, we consider it extremely important - adapting the ideas of Margaret Mead - that culture has many elements within a society, its meaning may change depending on the given local community, at the same time, communities of common ethnicity have universal cultural contents that distinguish the culture of a given ethnicity (in our case, Roma individuals) from the culture of the majority society. We define cultural difference as a product of this phenomenon.

Although we have already mentioned it in a different context before, we consider it important to mention it in terms of our definition of culture, that Roma culture is not considered a static phenomenon, because we assume that gypsy culture acclimatizes to a certain degree to the conditions of the age, all in such a way that it has constant elements that are independent of temporal coordinates.

From the point of view of our treatise, we considered it particularly important to clarify the conceptual framework of culture, because we represent the opinion that it is only possible to achieve a breakthrough result in the education of Roma students if the education system takes into account that it is an ethnicity that has cultural characteristics different from those of the majority society. In this connection, the researchers draw attention to the fact that Roma students enter the school system not only as members of society, but also as mem- bers of their own minority culture (Forray and Hegedús, 2003). This is also a very important moment, because the education policy must take into account that in this case it is not a matter of overcoming learning and study problems, because the problem of drop-out and school progress can be substantially remedied if the school system and their actors, educators, take into account that in the case of Roma students, the specific ethnic culture has an impact on the learning outcome.

The literature has been emphasizing for more than a decade that the primary goal of the majority of Roma individuals is not individual assimilation, but the idea of asserting themselves in society by preserving their own culture (Forray and Hegedús, 2003). In our treatise, we would like to draw attention to the fact that the school system must prepare Gypsy/Roma students for the skills that will enable them to adapt to both cultures. This actually means that Roma students have to socialize in several cultures, in their own minority or ethnic culture, and in the culture of the majority society. The theoretical, scientific background of socialization in several cultures is discussed in the next chapter.

\section{Socialization in multiple cultures}

There are several theoretical models in the literature that deal with the socialization of minority students. Of these, we highlight the cultural deficit model, which is based on the basic concept that the minority culture lacks several essential elements that are essential for the individual to succeed in the conditions of the majority society (Forray and Hegedûs, 1999). As a scene of secondary socialization, the school can provide a solution to fill in the gaps, through education and training. From the point of view of our research, we consider it important to mention the cultural deficit model because it provides a breeding ground for interpretations that classify Roma students in Hungary as disadvantaged or cumulatively disadvantaged. 
From the point of view of the scientific context of our study, we consider the dispositions of the bicultural socialization model to be remarkable, as it deals with the projections of socialization in the two cultures, a concept that is highly correlated with my doctoral empirical research. I am interested in the overlaps and differences between the socialization that took place in the minority community, in the narrower sense in the family, and the secondary, institutional, in our case, school socialization, and the consequences of this in the sample we examined.

Bicultural socialization is not the same challenge for all communities. An important factor is how close the two cultures, i.e. the minority and the majority, are. If minority culture conveys more values, norms, and patterns of behaviour that are authoritative in majority culture, then integration will be smooth. If the reverse is the case, intercultural socialization will face some obstacles (Diana, 1984). From this point of view, the curiosity of bicultural socialization can be grasped in that it directs the focus of attention to the parallel system of effects of socialization in the family and school, that is, in the institutional space.

In this sense, the success of a successful school career and social integration depends to a large extent on the degree of overlap between the two types of socialization. In Aranka Varga's interpretation, this appears as follows: „In the dual process of bicultural socialization, in addition to the acquisition of the cultural characteristics of family socialization, the effect of public education (kindergarten, school) appears, where the culture of the majority society is the content element of socialization. In relation to this duality, the theory of bicultural socialization clearly states that there are family socializations whose cultural content shows little overlap with the cultural space characteristic of the school." (Varga, 2015, 248.)

In the case of this type of family, a result can only be achieved if the actors in the bicultural field see it as their common task to match the two different spaces. Two main actors play an important role in carrying out the process. One such actor is the "mediator", who is at home in the cultural space of the education system and institution, school, and provides the most important information first hand (Forray and Hegedűs, 1999). Educators are typically „mediators”. They are the individuals who are able to build a relationship with the family, that is, the primary space of socialization. After learning about the cultural characteristics of the family, they seek to transfer the most important of these cultural features to the school world, which helps to broaden the overlap between the family and the school's socialization space. In this regard, we examine to what extent educators are able to play the role of "mediator" in primary schools that form the research field. We believe that educators can only be successful in this role if they are aware of the cultural background of the patterns of behaviour represented by Roma families.

Another important actor in bicultural socialization is the "translator". He is a person who comes from a family with a culture other than school, but despite the primary socialization space with a different culture, he has been able to achieve success in the socialization space of the school. As a result, it can convey to its own community the value system of the secondary socialization space. This is primarily justified by its credibility, and its system of tools is characterized by direct transmission and unobtrusive sampling (Fehérvári, 2015).

I consider it necessary to emphasize that in the case of bicultural socialization we are talking about a two-way process, and in reconciling two different cultures, it is legitimate for conflicts to arise. Consequently, continuous and direct communication as well as cooperation should be considered as one of the most important factors of bicultural socialization. By the way, the literature and our previous research argues that the most marked difficulties 
for Roma communities can be traced back to different time perspectives (Tóth, 2018). The way of life of Roma families is unstructured, which results in the time experience and the concept of time not developing (Józsa and Fejes, 2010).

Their daily activities are not time-bound, and this type of flexible time management is difficult to reconcile with the school's traditional time constraints. In many cases, large school absences of Roma students also stem from time constraints.

Overall, we can conclude that bicultural socialization is composed of many elements, and in the case of students from minority cultures, it is vital that the actors of the educational institution are aware of the points of contact between the two cultures. Forray and Hegedûs emphasized in this connection that the school should make an effort to have as many „translators” and „mediators” as possible systematically support the school progress of Roma pupils (Forray and Hegedûs, 1999).

In addition, it should be the responsibility of the school to inform members of the majority of society that students from minority culture, to a certain extent, have a specific set of values and norms and, as a result, have different attitudes and behaviours. If the process of bicultural socialization cannot be supported effectively enough by educational institutions, then the role attributed to the school, according to which the school can be seen as the channel through which social mobility can take place, or at least induce positive promotion, fails. In this case, the future perspective of the students may even be definitively sealed. Due to the importance of the phenomenon, in our paper we also examine the form in which schools can facilitate student mobility. The theoretical aspects of mobility and the school system are discussed below.

\section{The relation of social mobility, equality and school}

The relation between education and equality was in the focus of social scientific research between the two world wars. The majority studies on the subject reflect on the fact that individuals from different social classes have different chances in enrolling in certain types of school of the educational system. Lawton highlights the situation of the workers to introduce the problem as it is much harder for the children of the workers to be admitted in grammar schools (Lawton, 1974). Moreover, students from lower social classes tend to dropout from these schools.

Certain researchers, however, maintain a different approach towards the issue. James Samuel Coleman, for instance, defines the equality of education chances as one factor of efficacy. In accordance with this, Coleman came to the conclusion that the majority of scientific investigations pay too much attention to the role of school (Coleman, 1966). It is rather problematic as the school has no significant effect on the advancement of students, which is more likely determined by the social status of the parents. I think critique shall be applied in the regard of Coleman's approach, especially when the socially selective characteristic of the Hungarian educational system is taken into consideration.

Studies on social equality and school were first launched in the 1960's in Hungary, thanks to Zsuzsa Ferge's efforts. She destroyed the myth about the social equality in Hungary. Her researches revealed that there are strata in the Hungarian society that have better chances and there are other groups that have restricted access to advancement. Everything depends on the concentration of knowledge and power (Ferge, 1980).

It shall be emphasized, however, that status due to belonging to any social classes is not static and the possibility of social mobility is overt. As for the first step, the notion of social mobility shall be defined. The explanation of the concept, however, is rather problematic as we do not possess a framework system that provides exact information about the fact that at which point we may talk about social mobility. Notwithstanding, we can define par- 
ticular factors that directly or indirectly affect the process; these are the political and economic changes, individual or family events.

The interpretation of social mobility may be approached from multiple directions. On the one hand, there is an intergeneration mobility that reflects on the fact that how the individual moves in the social hierarchy compared to his or her parents. On the other hand, intrageneration mobility reveals the mobility of the individual in the career field. Most of the sociologists think that intergeneration mobility is more frequent in stable societies (Ferge, 1980).

One important distinction between intergeneration and intrageneration mobility is that the comparison of intergeneration mobility among different countries can be measured in a more precise way. There is also the phenomenon of circular mobility when certain individuals switch their places. It is possible to allude to the extent of the movements within the society. In accordance with this, a distinction is made between individual and collective mobility. In the case of the first, social conditions remain the same, however, in the case of the latter, these conditions are somewhat altered.

Regarding social mobility, Anikó Fehérvári draws the attention to the interpretation by Lipset and Bendix. The two researchers discussed the question of measuring mobility, that is to say, to what we compare mobility (Fe-hérvári, 2015). They think that social mobility shall be analyzed in time dimension or comparison as a certain society can be adequately described if it is compared to its earlier epoch or to a different country. Moreover, the scholars refer to a third alternative, the model of equal possibilities. According to this model, the ratio of mobility shall be disregarded and the inequality of possibilities leading to this road shall be taken into consideration instead. Finally, the name of Sorokin shall not be forgotten when discussing social mobility. He thought that vertical mobility is present in all societies. The education system of the
Church or military is included in the set of tools of such mobility, however, the most important one is the school. Sorokin compared school to an elevator that carries the people up and down.

He emphasizes that there are societies in which the elevator starts from the very bottom, however, there are certain other societies where it starts from the middle and the people at lowest classes of society have no access to such elevator at all (Sorokin, 1998).

Moreover, school is more than an educational institution, Sorokin states, as this is the venue where the social positions are selected. In certain cases, passing exams and meeting different requirements are used to select and distribute people to future social positions.

This is of high importance, Sorokin argues, because if the individual is unsuccessful in the school, he will be less likely to find another mobility channel apart from school. As a consequence of that, school has to be considered a fundamental key factor to future success.

\section{Conclusion}

On one hand, based on the theoretical scientific explanation, we can easily come to an agreement that the definition of culture and cultural difference can be approached from different kinds of aspects. One of the methods that a scholar can apply is to synthesize the variety of explanations in accordance with the conditions of the particular research.

On the other hand, the paper has argued that anthropology of education is unsurpassed in its richly detailed evocations of school failure. As such, it would be advisable to exploit the potential that anthropology of education provides. Sassi Abdelhafid also calls our attention to the phenomenon by claiming the following: ,... and even if anthropology may be seen as a time-consuming and a work of expensive methodology, this is not to reduce our awareness about the potentialities of the 
discipline in exploring and defining the educational space, as well as assessing and reforming the active framework of education, and moreover, forming knowledge about how change happens in the general education frame. Otherwise, educational anthropology may serve educational success by having right assumptions about the meaning of change in education regarding culture" (Sassi, 2008, 8.).

\section{References}

Anthony, G. (2008). Szociologia. Budapest: Osiris Kiadó

Clifford, G. (2001). Azértelmezés hatalma. Budapest: Osiris Kiadó

Coleman, J. (1966): Equality of Educational Opportunity. Government. Washington DC: Printing Office.

Diana, A. (1984). Bicultural socialization: Factors affecting the minority experience. Social Work, 29, 101-107.

Fehérvári, A. (2015). Társadalmi mobilitás és az iskola. In Varga, A. (Ed.). A nevelésszociológia alapjai Pécs: PTE NTI. 183-210.

Ferge, Zs. (1980): Társadalompolitikai tanulmányok. Budapest: Gondolat Könyvkiadó.

Forray, K. \& Hegedűs, A. (1999). Cigány gyermekek szocializációja. Budapest: Aula Kiadó

Forray, K. \& Hegedűs, A. (2003). Cigányok, iskola, oktatáspolitika. Budapest: Új Mandátum Kiadó

Hollós, M. (1993). Bevezetés a kulturális antropológiába. Budapest: ELTE BTK

Ionnais, S. (2012). Educational anthropology as a major approach for educational research: the beginnings and the evolution of educational anthropology, with an overview of its introduction in the Greek educational context. Journal of Arts and Humanities, 1, 18-26. doi: 10.18533/journal.v1i3.30

Józsa, K., \& Fejes, J. (2010). A szociális környezet szerepe a tanulási motiváció alakulásában: a család, az iskola és a kultúra hatása. In. Zsolnai, A.
(Ed.). A szociális kompetencia fejlesztésének elméleti és gyakorlati alapjai Budapest: Tankönyvkiadó. 134-162.

Kathryn, A. (2012). Introduction. Anthropologies and Ethnographies of Education Worldwide. In K. Anderson (Ed.), Anthropologies of Education. United States: Berghahn Books. 1-28.

Kende, Á. (2001). A kudarcok okai. In Andor, M. (Ed.). Romák és oktatás. Pécs: Iskolakultúra. 6573.

Lawton D. (1974): Társadalmi osætály, nyelv, oktatás. Budapest: Gondolat Kiadó.

Leach, A. (1996). Szociálantropológia. Budapest: Osiris Kiadó

Letenyei, L. (2012). Kulturális antropológia. Budapest: Typotex Kiadó

Milton, Y. (2002). Az asszimiláció és disszimiláció felé. Regio, 13, 24-44.

Németh, A. \& Pukánszky, B. (1996). Neveléstörténet. Budapest: Nemzeti Tankönyvkiadó

Niedermüller, P. (1994). Paradigmák és esélyek. Replika, 13, 89-129

Prónai, Cs. (1995). Cigánylkutatás és kulturális antropologia. Budapest: ELTE BTK

Sassi, A. (2008). Educational anthropology. A theoretical exploration. Revue Faculté des Lettres, 14, 714.

Sorokin, P. A. (1998): Az egyének társadalmi rétegenkénti minősítésének, kiválasztásnak és elosztásának mechanizmusai. In Róbert, P. (Ed.): A társadalmi mobilitás: Hagyományos és új megközzelitések. Budapest: Új Mandátum Kiadó. 12-25.

Tóth, N. (2018). Kótaj község területén élő oláh cigány közösség szociokulturális helyzete és iskolázottsági viszonyai. In Bocsi, V.(Ed.). Oktatás - Nevelés - Társadalom. Debrecen: Didakt Kiadó. 208-221.

Varga, A. (2015). Esélyegyenlőség és inklúzió az iskolában. In Varga, A. (Ed.). A nevelésszociológia alapjai Pécs: PTE NTI. 241-272. 